\title{
ONE ARMY, TWO SYSTEMS. MILITARY JUSTICE IN TRANSYLVANIA, DURING THE SECOND CAMPAIGN OF THE WAR OF REUNIFICATION 1918-1920
}

\author{
Col. (ret) Prof. Ion GIURCĂ, PhD* \\ Col. Liviu CORCIU, PhD Candidate**
}

In the middle of the campaign for Transylvania's liberation, the Governing Council of Sibiu had decided to support the efforts of the Romanian army and ordered the establishment of a Territorial General Commandment meant to begin recruitment in Transylvania, Banat and the Romanian provinces in Hungary, in order to constitute an unit of volunteers. Ulteriorly, out of their ranks, 6th and 7th Army Corps have been established, recruited exclusively from Transylvanians regardless of their nationality. Under Decree I passed by the Governing Council of Sibiu, laws, ordinances, regulations and legal statutes issued prior to December 18th1918, when Transylvania was proclaimed independent of Budapest, were temporarily in force. Within this context, militaries of Transylvanian divisions were subject to military jurisdiction under Austro-Hungarian Military Criminal Code of 1855, whereas Romanian militaries who were under the command of Transylvanian Commandment of Troops were subject to the jurisdiction of Romanian laws, implicitly to the Code of military justice.

Keywords: military justice; discipline; disobedience; court martial; campaign.

The topic approached in this current paper is specific not only to the military body, but also to the entire legislation within Romanian territories united subsequent to the War of National Reunification. At the time the Great Unification took place in the Old Kingdom, the Criminal Code and the Criminal Procedure Code of 1864 were into force, in Transylvania the Hungarian Criminal Code of 1878 and the Criminal Procedure Code of 1896, in Bessarabia the Russian Criminal Code of 1903 and the Criminal Procedure Code of 1864, whereas in Bucovina, the Austrian Criminal Code of 1852 and the Processual Code of $1873^{1}$.

We will attempt to continue presenting, the way we had learned in our documentation, the links between legislative inconsistencies from the two territories inhabited by Romanians, the lack of endowment with specialized personnel within martial courts and the disciplinary stance of some of the volunteer units comprised by Transylvanian divisions, during the second campaign of the Reunion War.

According to the provisions laid down under the armistice signed in Beograd on November

\footnotetext{
*"Carol I" National Defence University e-mail:ion_giurca@yahoo.fr

** Romanian National Military Archives

e-mail:liviu.corciu@yahoo.com
}

$13^{\text {th }} 1918$, across the flow line of Mures river a demarcation line was established which underwent a sinuous course, from Rodnei Mountains, to the North, crossing Bistrița, Târgu Mureș, Alba Iulia, Deva, southern Arad and further westwards towards Szeged and Pecs, line which set up the boundaries up to which the Romanian army could march forward in Transylvania and Banat.

The very first military actions in Transylvania were carried out by subunits of the Border Guard Corps HQ, starting from October $29^{\text {th }} /$ November $11^{\text {th }}$ 1918 , having the mission to enable the concentration ${ }^{2}$ of the main forces of $7^{\text {th }}$ Infantry Division and $1^{\text {st }}$ Light Infantry Division in western Carpathians.

The first elements fit for the value of a reinforced infantry regiment of $1^{\text {st }}$ Light Infantry Division commanded by General Aristide Lecca, respectively, from $7^{\text {th }}$ Infantry Division commanded by General Traian Moșoiu, Transylvanian at heart, crossed the Carpathians on November $10^{\text {th }} / 23^{\text {rd }}$ and $11^{\text {th }} / 24^{\text {th }} 1918$. Their task was to secure an operational alignment on the flow line of Mures River, and to concentrate their efforts ${ }^{3}$ towards the spring of Mureș River, within the Toplița-DitrăuGheorghieni area, respectively, the spring of Olt River, within the Sândominic-Dănești-Miercurea Ciuc area.

Without encountering serious opposition, on November $17^{\text {th }} / 30^{\text {th }} 1918$, the elements belonging 
to $7^{\text {th }}$ Infantry Division which went forward entered Reghin, and two days afterwards Târgu Mures; on November $17^{\text {th }} / 30^{\text {th }} 1918,1^{\text {st }}$ Light Infantry Regiment occupied Miercurea Ciuc, whereas on the same day, $6^{\text {th }}$ Light Infantry Regiment occupied Brașov.

Due to Hungarian infringement of the provisions of the Beograd Armistice Convention, on November $29^{\text {th }} /$ December $12^{\text {th }} 1918$, the Romanian General Headquarters solicited ${ }^{4}$ the Danube Army Headquarters, the agreement of Allied Powers to cross the demarcation line established across the flow line of Mureș River, both for replying to the appeal of the Consiliul Dirigent that had solicited an immediate intervention, and for counter-tackling the reorganization and concentration of Hungarian forces within the concealment of delimitation line, and by this way to hinder the spreading and propaganda of anarchist ideas.

Within this context, the Romanian General Headquarters ordered the Transylvanian Troops HQ, established on December $11^{\text {th }} / 24^{\text {th }} 1918$, to occupy all Romanian territories which had been part of the former Austro-Hungarian monarchy, save for Banat, already occupied by French and Serbian forces, in order to ensure order, life and welfare of inhabitants. On December $11^{\text {th }} / 24^{\text {th }} 1918$, $7^{\text {th }}$ Infantry Division soldiers entered Cluj, and in Sibiu, General Traian Mosoiu was welcomed as a hero.

Besides all the remobilized and established division HQs, starting January 1919, courts martial were to be established in order to sanction all infringements of provisions of military laws and regulations.

\section{National Guards}

Romanian Army units recruited in Transylvania, also known as Transylvanian Divisions, were subsequent to the national guards which were first established ${ }^{5}$ on October $18^{\text {th }} / 31^{\text {st }} 1918$, the process going further on in November and December. At rural level, the guards were structured according to territorial principles, in each commune mostly inhabited by Romanians, a national guard was to be established, with the mandatory requirement that the number should not exceed $5 \%$ of commune population.

The guards had no special uniforms, therefore using either the old Austro-Hungarian uniform or civilian attire, but had the obligation to wear a tricolor armlet on the left arm, on which the words "Romanian National Guard" were written.

The efficiency of these structures which reached by end of November 1918 a number of $8,000-10,000$ people was proven when it came to the defence of freedom of movement of the delegates from the Great National Gathering from Alba Iulia, when using armed forces, the liberated the railway blockades from Cucerdea, Teius,, Podul Mureș and Coșlar, previously occupied by Szekler forces. In the meantime, more than 3,000 National Guard members ensured the order and safety of the delegates in Alba Iulia ${ }^{6}$.

Therefore, after the surge generated by the national feeling had been calmed down, after a decision ${ }^{7}$ of the Public Defence and Security Sector within the Consiliul Dirigent from December $9^{\text {th }} / 22^{\text {nd }} 1918$, the gradual abolition of Romanian National Guards within liberated territories followed, which had become a danger, as recorded in a report ${ }^{8}$ by Transylvanian Troops HQ, although they had been truly useful at the beginning under the enthusiasm of the revolution.

The National Guards had been replaced by specialized gendarme and police forces, although their implementation lasted a long time. However, Transylvania lacked proper organization, especially because most of the administration had been settled with Hungarian clerks, which had retreated together with the former sovereignty.

That was why, Consiliul Dirigent called up ${ }^{9}$ Romanian officers and militaries of all ranks, which had served in the former Austro-Hungarian army, thus organizing 15 companies of Transylvanian gendarmerie, which had the mission of disarming population and replacing local national guards.

Out of these forces, later on, the first Transylvanian gendarmeregiments was established, headquartered in Brașov, Cluj and Arad, which gradually began to replace operational forces within services of maintaining order and the safety of communication ways within Transylvania.

In the Austro-Hungarian army, characterized by a complex structure and a multinational character ${ }^{10}$, $30^{\text {th }}, 63^{\text {rd }}$ and $64^{\text {th }}$ Regiments were exclusively Romanian, to which 13 more regiments were added comprising over $50 \%$ Romanians, initially totalizing, at the beginning of the war 72,000 militaries ${ }^{11}$. 
In 1915 Romanian forces comprising AustroHungarian units reached 200,000-300,000 militaries, who had taken part in the Eastern Front Campaign, in Galicia, but also on the Balkan and Italian fronts, being praised both in official communications as well as by Hungarian press.

In an article published on August $18^{\text {th }} / 31^{\text {st }}$ 1915 in the Adevărul newspaper by publicist Ion Grecu, entitled "Romanian Regiments Sentenced to Death. What does Hungarian Praise Mean", the public was shown the battle course of one of these regiments, praised by Hungarian press, according to the author, only after having been "molten" by countless assaults against Russian cannons: "Because Hungarian press (...) praises Romanian soldiers only after they are dead (...). Hungarian praise towards a Romanian regiment means that a new regiment is sentenced to die and that sentence performance had begun" 12 .

However, the bravery of Romanian soldiers serving the Austro-Hungarian army was also recognized by imperial authorities, $50^{\text {th }}$ Regiment of Alba Iulia being the only one from the entire dualist monarchy bearing the golden medal on the flag, and for its contribution in the Galician Campaign, the flag of the regiment was decorated by emperor Wilhelm II with "The Iron Cross"13 .

\section{Establishment of Transylvanian Divisions}

Simultaneously with Romanian army action in Transylvania, Consiliul Dirigent decided to support the liberating efforts and ordered the establishment ${ }^{14}$ in Sibiu, on January $5^{\text {th }} / 18^{\text {th }} 1919$ of the Territorial General Command (known in some documents as the A.B.U. Territorial Command), under the command of General Ioan Boeriu, having the mission to start recruiting in Transylvania, Banat and within territories inhabited by Romanians in Hungary, in order to create some Transylvanian volunteering units.

Approximately in the same period, LawDecree no. 345 of January $25^{\text {th }}$ February $2^{\text {nd }} 1919$, decided, following to be subsequently ratified by the legislative bodies, the establishment of $6^{\text {th }}$ and $7^{\text {th }}$ Army Corps, with $16^{\text {th }}, 17^{\text {th }}, 18^{\text {th }}, 19^{\text {th }}, 20^{\text {th }}$ and $21^{\text {st }}$ Divisions, exclusively recruited amongst Transylvanian inhabitants ${ }^{15}$.

The bill had been initially drawn up due to the proposal of the Ministry of War of that time, Army Corps General, Arthur Văitoianu, and was meant to regulate the rights and duties of Transylvanians when exerting military service, and sought at the same time to apply Romanian military organization within a new territory, of principles of organizational and recruitment laws, as well as those referring to position of officers, allowances, marriage, pensions, etc.

Although the provisions from art.2, Law-Decree no. 345 established that all Romanian military regulations were also applicable to these units, the lawmaker seems to have taken into account the impartial reality of the situation, involving also a certain transitional stance, which was to be regulated under ministerial decisions.

The impartial reality of the situation was taking into account both the fact that those concerned did not know the laws, as well as the necessity of interoperability of the new structures, that most volunteers came from ex-POWs from the Serbian, Italian or Galician fronts. To those mentioned above, one must add the lack of training of the officers and soldiers under the regulations of the Old Kingdom, as well as language barriers, taking into account that the troop was to be recruited from more nationalities, save for Hungarian.

In order to implement Law-Decree no. 345, Ministerial Decision no. 40 was issued, which established firstly the constitution of $16^{\text {th }}$ and $18^{\text {th }}$ Infantry Divisions, as well as the method of operating with officers, organic composition of troop corps, weaponry, ammunition, and equipment to be distributed ${ }^{16}$, etc.

Alexandru Hanzu, former Austrian army colonel, originally from Săliște, Sibiu county, who became General of the Romanian Army on April $11^{\text {th }} 1919$, had been appointed commander of $16^{\text {th }}$ Infantry Division.

Dănilă Papp, former colonel in the Austrian Great General Staff, professor within the Military Academy of Vienna, and remarkable commander on the Russian front ${ }^{17}$, originally from Bihor county, promoted in turn to General of the Romanian Army on April $11^{\text {th }} 1919$, was appointed as commander of $18^{\text {th }}$ Division.

Military Justice within the two divisions, according to art. 9 of Decision no. 40, was to be administrated according to Romanian Code of Military Justice, by courts martial, inspired by those from the Romanian Army, but having implemented some measures imposed by the transitional period. 
In order to implement the provisions of the aforementioned two norms, on March $1^{\text {st }} 1919$, in Sibiu, the Organization Service of $6^{\text {th }}$ and $7^{\text {th }}$ Army Corps (6-7 OS) was established, under the command of general Ioan Boeriu, directly subordinated to The Ministry of War, having the mission of coordinating mobilization, equipping and training activities of Transylvanian divisions, but which also targeted unitary military organization of Transylvania, Banat and Maramureș ${ }^{18}$.

Until March $27^{\text {th }} 1919$, mobilization of $16^{\text {th }}$ and $18^{\text {th }}$ Infantry Divisions' units had been mainly done, their forces comprising, besides volunteers arrived in 1917 and trained in Moldavia, many militaries from the former Austro-Hungarian army, demobilized after the Armistice of Villa Giusti.

The Structure of those divisions was almost identical with the structure of infantry divisions existing within the Romanian army, comprising also infantry, artillery regiments, light infantry and engineer's battalions, as well as a campaign hospital.

Distribution of troops in peace garrisons of $16^{\text {th }}$ Infantry Division's units was the following: $81^{\text {st }}$ Infantry Regiment in Dej, $82^{\text {nd }}$ Infantry Regiment in Târgu Mureș, $83^{\text {rd }}$ Infantry Regiment in Cluj, $84^{\text {th }}$ Infantry Regiment in Bistrița. To these artillery units and a light infantry battalion were added, totalizing 10,590 men $^{19}$.

$18^{\text {th }}$ Infantry Division distribution was $89^{\text {th }}$ Infantry Regiment in Brasov, $90^{\text {th }}$ Infantry Regiment in Sibiu, 91 ${ }^{\text {st }}$ Infantry Regiment in Alba Iulia, 92 ${ }^{\text {nd }}$ Infantry Regiment in Orastie, to which there were added artillery units, a pioneer battalion and a light infantry battalion, totalizing 11,210 $\mathrm{men}^{20}$.

As a consequence to the worrying evolution on the Transylvanian front, since on March $25^{\text {th }} 1919$ the new government in Budapest had declared war to all neighboring countries, the Romanian General Headquarters ordered 6-7 OS to mobilize the two divisions starting with April $1^{\text {st }} 1919$, after which within 10 days they were to be at the disposal of operational HQs ${ }^{21}$.

Therefore, on April $1^{\text {st }} 1919,16^{\text {th }}$ and $18^{\text {th }}$ Infantry Divisions were taken out of 6-7 O.S. subordination, being directly operationally and administratively subordinated to the Transylvanian Troops HQ, respectively, to the Romanian General Headquarters, after which they were to be assigned to missions and to carry out military actions together with the Old Kingdom units ${ }^{22}$.

\section{One army, two systems of military justice}

$16^{\text {th }}$ and $18^{\text {th }}$ Infantry Divisions left for the operational area, having military justice officers in order to implement laws according to the provisions of Law-Decree no. 345 of January $25^{\text {th }} /$ February $7^{\text {th }} 1919$, more precisely according to the Romanian military regulations and laws, when the units subordinated to the Transylvanian Troops HQ were located on the Apuseni Mountains' alignment. A court martial ${ }^{23}$ had been also created within the vicinity of O.S. 6-7, but which was functioning according to Hungarian laws ${ }^{24}$. General Gheorghe Mărdărescu, commander of the Transylvanian Troops HQ was not very satisfied with its performance, having even solicited assignment of officers from the Old Kingdom with legal experience "because the way things work in that service, leaves excessively to be desired" 25 .

The situation was known, because ever since February $5^{\text {th }} 1919$, when he was the commander of the Territorial General Command, subordinated to Consiliul Dirigent, General Ioan Boeriu, initiated a report, registered as no. 44 of February $18^{\text {th }}$ 1919, both to the Ministry of War and Consiliul Dirigent.

He referred ${ }^{26}$ to the consequences of the Decree no. I entitled"ecree about the temporary functioning of public services, law implementation, clerks and language utilization", actually about the fact that the laws, ordinances, regulations and legal statutes issued prior to October $18^{\text {th }} / 31^{\text {st }} 1918$, date when Transylvania had been proclaimed independent of Budapest, had temporary remained into force "suiting the interest of public order and to ensure rightful continuation" 27 .

Therefore, according to those recorded in the report, militaries of Transylvanian divisions which were in the constitutive process, were subject to military jurisdiction under Austro-Hungarian Military Criminal Code, promulgated on January $15^{\text {th }} 1855$. To its provisions the Hungarian law article XXI ex. 1890, regarding punishment for disobedience towards the call up under flag order and the seducement to such an offence, the Hungarian law article XXX ex. 1912, regarding criminal provisions of the law upon armed power and other laws concerning fulfillment of military service obligations, as well as the Hungarian law article XXXII ex. 1912, regarding military criminal procedure were added. 
The report caused no change of the attitude of the Consiliul Dirigent which, subsequently, on February $21^{\text {st }} 1919$ issued the "Order no. 30301 regarding military justice", which regulated the way it was about to administer military justice within the entire territory "added" to the Old Kingdom (Transylvania, Banat, the territories inhabited by Romanians in Hungary ${ }^{28}$, subjected from a military-administrative point of view to 6,7 O.S.

Therefore, in Sibiu, a military court was to be established under provisions of Austro-Hungarian law, its jurisdiction was to comprise all the militaries subjected to O.S.6,7, as well as civilians who under existing laws were eligible on the side of the military judicial forums.

The order was also mentioning the fact that, given the mobilization stance, the court was to follow the campaign procedure, under chapter XXVII of Hungarian law military criminal procedure, the O.S. 6,7 commander having the processual attributions of the upper echelon.

The order also established a subsidiary in Cluj of the military court from Sibiu, in charge with causes concerning troops quartered in Cluj, Mureș and Solnoc-Dăbâca ${ }^{29}$ counties, and established a military prison facility in Cluj and Sibiu garrisons.

We need to state the fact that according to art.59 of the Military Criminal Code of the former AustroHungarian army ${ }^{30}$, arrest in garrison imprisonment was applied to soldiers ranked up to sergeant, to those who had been subject to military demotion as an auxiliary punishment, wives and children of all those previously mentioned, as well as to civilians for acts within the competence of military justice.

Minimum duration of arrest was 24 hours, and maximum duration was 6 months, within special circumstances this term could be exceeded. Also, according to art.77 under the same Military Criminal Code, the imprisonment punishment could simultaneously be added several "aggravations", such as fasting, when the convict was fed several days in a row only with bread and water, the hard sheet, not more than twice a week, solitary confinement, not more than 14 days in a row, labor in the barracks or camp, etc.

Coming back to the way of applying military justice in the Transylvanian campaign, more precisely to the simultaneous and specific existence of every law-making entity, both in Transylvania, as well as in the Old Kingdom, of the own regulatory framework within the domain, under legislation applicable within its territory, General Ioan Boeriu initiated a new step.

This time, together with the emergence of Law-Decree no. 345 of January $25^{\text {th }} /$ February $7^{\text {th }}$ 1919 and the issuance by the Ministry of Law of the "Decision no. 40 of January $20^{\text {th }} /$ February $2^{\text {nd }}$ 1919, which we had presented before, he addressed to the Consiliul Dirigent by Report no. 11442 of April $21^{\text {st }} 1919$, informing the Justice Sector which was comprised within that there are inconsistencies regarding military justice administration to United Romania's troops and formations ${ }^{31}$, between provisions of Decree no. I of January $24^{\text {th }} /$ February $6^{\text {th }} 1918$ and the provisions of Law-Decree no. 345, respectively of Decision no. 40.

General Ioan Boeriu, informed the Consiliul Dirigent about the legal framework applicable to military justice, confirming the prior agreement of the Romanian General Headquarters, communicated to the Chief of the General Staff of the Territorial General Command, at that time colonel Dănilă Papp, regarding the approval for Transylvanian divisions to establish, in their initial stance, their own courts martial.

Explaining to Consiliul Dirigent the possibility that Transylvanian Divisions, acting within military circumstances alongside the Old Kingdom divisions, as required by operational interests, to subordinate some of these units and the other way around, General Ioan Boeriu was wondering whether "is it good and efficient for Transylvanian divisions within criminal justice operational area to follow other laws as the divisions of the Old Kingdom?"32.

Out of his explanations, one could notice the incompatibility of the legal framework regarding military justice administration, both in terms of competence, as well as criminal procedure. According to article XXXII of Austro-Hungarian law, in campaign procedure, criminal justice fell under the competence of the division or army corps commander, through the legal officers that were nominated to him, situation in which soldiers from the Old Kingdom, reaching in the operational course the orders of a Transylvanian division commander, should have been judged following the former Austro-Hungarian army laws, which would have represented an infringement of the principles of the Romanian Constitution. 
Things were no different even from the point of view of criminal procedure, taking into account at least two factors. First, the Austro-Hungarian army military criminal procedure had no way of appeal, whereas the Romanian Code of military Justice had the option of recourse to the Permanent Revision Council. The argument was solid, since the provisions of the High Royal Decree no. 2930 of September $16^{\text {th }} / 29^{\text {th }} 1916$, respectively, of the High Royal Decree no. 7 of January $7^{\text {th }} / 20^{\text {th }} 1917$, under which the right to recourse had been suspended, respectively lifted, had been abrogated under Law no. 2254 of August $28^{\text {th }} 1918^{33}$.

The second factor concerned the procedure itself, precisely the fact that if the competent commander had submitted a sentence, deemed by him as being illegal, to the upper echelon in order to be quashed, according to the former AustroHungarian army military criminal procedure, this processual attribution would have been assigned to the commander of the Transylvanian Troops HQ, being thus faced with applying a foreign law, aspect forbidden by the same Constitution.

"I therefore suggest, Ioan Boeriu was concluding his report, to decree that military justice within Transylvanian division and unitary units located in operational area (...) criminal military justice to be made according to Old Kingdom laws, and to the other Transylvanian troops, respectively troops outside operational area, as well as the civilians subject to military jurisdiction in this territory, to have the laws applied as decreed by Consiliul Dirigent"34.

Although Consiliul Dirigent allowed within the text of "Decree no. I "the possibility for some derogations, explaining that laws, ordinances, regulations and legal statutes issued prior to October $18^{\text {th }} 1918$, were temporary into force, "with the exception of those comprised by the current decree, and in other ulterior decrees", there were no substantial amendments, neither were there any exceptions notified regarding military justice administration.

The Governing College persevered in maintaining its own jurisdiction and procedures regarding Transylvanian divisions, although there seem to have been opportunities of legislative harmonization. Specifically, another bill initiated by General Ioan Boeriu, under which he was asked for some modification of worth limit for offences "originating from will of desire" 35 , motivating that they had been established in 1895, when the Austro-Hungarian Military Criminal Code was promulgated, and no longer corresponded to economic and social references of 1919, had been adopted by Consiliul Dirigent under "Decree no. XIII" of May $20^{\text {th }} 1919$, entitled "Decree regarding modification of some provisions of the AustroHungarian military criminal code, amended on January $15^{\text {th }} 1855$, and of the military criminal procedure applicable to the Romanian territorial armies from Transylvania, Banat, and the Territories inhabited by Romanians in Hungary" 36 .

The only modification brought to the administration of military justice, under this new decree, was that sentences pronounced by courts martials of Transylvanian divisions were to be no longer given "in the name of the emperor", but "in the name of the law".

\section{Disciplinary status within Transylvanian divisions}

Legal and procedural uncertainty among Transylvanian divisions had been also reflected in the disciplinary status of some of the newlyestablished units, especially because the ideas of the Bolshevik revolution were shattering not only Hungary, but also the entire European continent and naturally, they also affected the Romanian soldiers from the former Austro-Hungarian army.

The morale, the material and disciplinary status of Transylvanian forces, distributed in garrisons within internal area, were illustrated in a report from General Ioan Boeriu addressed to the Transylvanian Troops HQ, about an incident where $81^{\text {st }}$ Infantry Regiment soldiers had brutally assaulted some gendarmes: "Most of these elements are soldiers who returned from Russian captivity, who had been through the Hungarian revolution filled with impulses hostile to the sovereignty of state. Their disposition towards revolt is also nourished by the deplorable circumstances the soldiers from this garrison are facing (Dej garrison), most of them are improperly dressed, barefoot and without bedsheet (...)" ${ }^{37}$.

The state of mind was not very different between $16^{\text {th }}$ and $18^{\text {th }}$ Infantry divisions distributed in operational area. By a telegram addressed to the Transylvanian Troops HQ, General Traian Moșoiu informed on April $23^{\text {rd }} 1919$ that Transylvanian 
forces from some units belonging to $16^{\text {th }}$ and $18^{\text {th }}$ Infantry divisions manifest lack of discipline, the officers from these units "being morally and materially unable to hinder them" 38 .

In order to remove this evil which was in his opinion "the germ of disorder", General Traian Moșoiu suggested that for each division, one country detachment of gendarmes to be attached, under the command of at least 3 to 4 energetic gendarme officers, who would be able to immediately repress any abuse.

On the same day, also in a telegram, the resolution of General Gheorghe Mărdărescu was communicated: "It shall be ordered to immediately report the measures adopted. I hereby declare the division commanders directly responsible for slipping on this slope. Courts martial, they also need to function and repress with their entire rigor these acts of wildness" 39 .

As consequence, the commanders of the two divisions were notified ${ }^{40}$ by "Order no. 5090" of April $25^{\text {th }} 1919$, about their subordinated troops misbehavior and also about the concern of the superior echelon regarding the order and discipline amongst them, since the it gravely affect the prestige and honour of the Romanian army.

Besides, $16^{\text {th }}$ and $18^{\text {th }}$ Infantry divisions had been ever since April $1^{\text {st }} 1919$ at the disposal of the Transylvanian Troops HQ and had already left for the operational area, according to what the report recorded, legal officers being assigned, in order to apply justice according to the aforementioned laws (laws applied in the former Austro-Hungarian army).

General Dănilă Papp's reaction to the accusations brought against his subordinates came no later, so that, on April $28^{\text {th }} 1919$, he reported the situation to General Gheorghe Mărdărescu ${ }^{41}$.

Although he accepted that there were some units where the soldiers had committed acts of indiscipline which were under investigation, according to $18^{\text {th }}$ Infantry Division commander the situation of his troops was no different from the entirely Transylvanian social behavior of that time. That behavior was facing a void when it came to authority, not only in administration, but also in all sectors of social life, both as having been proclaimed independent of Budapest, as well as due to the Bolshevik revolution, which was fully underway on Hungarian grounds.
As far as troop discipline was concerned, although their gradual mobilization had been attempted, taking into account their education ever since they had entered the units, wrote General Dănilă Papp, the operational events sped the process up. The daily arrival within units of approximately 200-400 recruits, doubled by the lack of officers, not more than 20 for each regiment, out of which most did not yet know Romanian, lack of noncommissioned officers and the need of time in order to train all of them, equally contributed to the situation.

Another cause, claimed General Dănilă Papp, was the request of Transylvanian Troops HQ to have over 5,000 people involved in guard missions of the railways due to the March $15^{\text {th }} 1919$ strike, mission which caused the training to fall from the top interest. This aspect had been reflected also in the disciplinary stance: "A systematic discipline implementation, which according to the morale of the people would have been necessary, could not be made and the regiments proceeded untrained to the front. The guilty ones shall always receive the deserved punishment" ${ }^{\prime 2}$.

Having all these assurances, at the beginning of July 1919, despite being located on Tisa River, in the vicinity of Szolnok, $18^{\text {th }}$ Infantry Division still did not have a military prosecutor (royal commissioner), although, the Transylvanian Troops HQ had sent a telegram to the Romanian General Headquarters in order to receive one "or at least a substitute of military prosecutor", according to the request "since this court cannot currently function because the actual military prosecutor does not know the [Romanian] laws" ${ }^{43}$.

In the absence of any explicit order this telegram may be considered a proof that Romanian General HQ did not accepted a dual administration of the military justice, or at least did not accept it for 16th and 18th divisions, which were subordinated through the Transylvanian Troops HQ, already involved in military actions alongside Old Kingdom's units.

The administration of military justice within $18^{\text {th }}$ Infantry Division seems to have actually represented an issue since on July $14^{\text {th }} 1919$, the Transylvanian Troops HQ sent another telegram to the Romanian General Headquarters, in order to tell the fact that, although three assignment requests for a substitute of military prosecutor had been transmitted to the JAG's office of the $18^{\text {th }}$ 
Infantry Division court martial, the request was still unsolved.

This new step had been initiated as a consequence to a new request from General Dănilă Papp, who had warned the Transylvanian Troops $\mathrm{HQ}$, that "due to dysfunctional military justice, discipline is highly jeopardized" 4 .

Being convinced in turn by the urgent character and the justness of the submitted arguments, General Gheorghe Mărdărescu, emphasized towards the Romanian General Headquarters the necessity of distributing one substitute of military prosecutor to each prosecutor's office of $16^{\text {th }}$ and $18^{\text {th }}$ Infantry Divisions' courts martial, who was to guide the work, otherwise they would not function.

However, court martial of the $16^{\text {th }}$ Infantry Division was functioning or at least this can be understood from "Report no. 710" of June $26^{\text {th }} 1919$ issued by General Gheorghe Mărdărescu, with the purpose of informing the Romanian General Headquarters about the performance of the death sentence of three militaries, sergeants Gondosch Mihail and Boschzer Mihail, respectively, soldier Friss Nistor. They had been judged on June $14^{\text {th }}$ 1919 by $16^{\text {th }}$ Division court martial, having been found guilty of "agitating the spirit of their comrades, urging them to no longer obey military laws, to kill officers or leave the front" ${ }^{45}$, and their sentences had been communicated to all divisions in order to be read in front of the troops "under arms".

Within $16^{\text {th }}$ Infantry Division, the Transylvanian Troops HQ had requested the Romanian General Headquarters ever since June $8^{\text {th }} 1919$, to send a military prosecutor together with all the necessary laws and regulations, because the division had reported that due to these shortages the court martial could not function properly ${ }^{46}$.

With all these repeated requests, it was only on July $5^{\text {th }} 1919$ when the JAG managed to select several officers: $1^{\text {st }}$ lieutenant (r) Albert Lee and $2^{\text {nd }}$ lieutenant (r) Ion Dumitrescu, for $16^{\text {th }}$ Division court martial, respectively $1^{\text {st }}$ lieutenant (r) Constantin Balescu, for $18^{\text {th }}$ Division court martial, but the officers had not arrived yet, and other licensed officers, who had already been mobilized, were not available ${ }^{47}$.

$16^{\text {th }}$ Infantry Division court martial was functioning ever since July $5^{\text {th }}$ following the Romanian Code of military justice, according to a telegram ${ }^{48}$ dated August $20^{\text {th }} 1919$, and assignment, was as it follows: Captain Nicolae Negreanu, $1^{\text {stlieutenant }}$ Albert Lee and $2^{\text {nd }}$ lieutenant Ion Dumitrescu. On August 28 ${ }^{\text {th }}$ 1919, this personnel was completed by Captain Aurel Bozac, former auditor (military prosecutor) within the AustroHungarian army, $1^{\text {st }}$ Lieutenant Vasile Crăciun, magister on probation and $2^{\text {nd }}$ lieutenants Alexandru Țandrău, Emil Furcaș and Valeriu Simonetti, all three law students ${ }^{49}$.

However, it seemed like there was no sign of solid results, since with "Telegram no. 876" of October $7^{\text {th }} 1919$, the JAG from the General Headquarters addressed to $16^{\text {th }}$ Infantry Division commander, warning him about the unreliability of the personnel of his division's court martial due to which: "many swindlers are on the verge of averting punishment" ${ }^{\prime \prime}$.

Since on July $20^{\text {th }} 1919$ the offensive of the Red Hungarian Army had begun, which had succeeded to develop more bridge heads on the eastern bank of Tisa River, Transylvanian Troops HQ was submitting to the Romanian General Headquarters through "Telegram no. 8152 " of July $22^{\text {nd }} 1919$, the report no. 778 by General Dănilă Papp, regarding $18^{\text {th }}$ Infantry Division situation, where the state of spirit was not good at all: "this division's infantry is completely demoralized" 51 .

"The wind of revolution affected these troops", motivated $^{52}$ General Dănilă Papp, attempting to explain to his superiors what caused these states, "destroying even the last remnant of discipline from their soul".

Among other causes that had generated that attitude of the troops, General Dănilă Papp also blamed it on lack of necessary time for organization and training, after the recruitment process had ended, within regiments, the divisional forces being brought directly from the front, their fatigue, taking into account that Transylvanians were at war for five years, as well as lack of an adequate motivation, because the regiments of the division operated West from Tisa River, "a region soldiers know that it won't belong to us" ${ }^{53}$.

Last but not least, $18^{\text {th }}$ Infantry Division commander was mentioning that up to a great extent, the fact that until the date of the issuance of the report, July $22^{\text {nd }} 1919$, not even a single case of indiscipline had been brought before the court martial of the division, which had been banned 
from judging according to Hungarian laws, and personnel to know the laws and procedures of the Old Kingdom had not arrived until then, also contributed.

The disciplinary situation of the forces comprised by the Transylvanian divisions seemed to worry the Romanian General Headquarters, or at least this way one could interpret "Order no. 9732" of July $24^{\text {th }} 1919$. Being inspected by Transylvanian troops, General Constantin Prezan, the Chief of the Romanian General HQ had telegraphically ordered the $2^{\text {nd }}$ Army Corps to immediately send to the Transylvanian divisions four substitutes military prosecutors, "from the skillful, energetic and experienced magistrates" 54 because when lacking competent personnel, the courts martial of the two divisions could not function.

"It cannot be punished as deserved" was recorded in the telegram ${ }^{55}$ through which the order had been transmitted, "the various cases of deviation from duty, theft, fleeing from the front, indiscipline, desertions, etc. which are abundant in these divisions". According to the specifications from the order, $2^{\text {nd }}$ Army Corps was to select officers on the same day, according to mentioned criteria, among the magistrates of the courts martial of subordinated divisions, those being about to go to the designated units even the following day.

We are required to mention that not all Transylvanian units had manifested a low combat spirit and a precarious disciplinary state. One of the units with forces recruited exclusively in Transylvania distinguishing from the others was the Regiment "Beius", made up exclusively of Romanian from the region of Apuseni Mountains, volunteers originating from the areas of Brad, Baia de Criș, Campeni, Abrud and Hălmagiu ${ }^{56}$.

On June $18^{\text {th }} 1919$, General Ștefan Panaitescu, chief of staff of the Transylvanian Troops HQ, was telegraphically reporting to the Romanian General Headquarters about the performance of the regiment in the battles on Tisa River: "Beiuș Regiment behaved very well in the operations it had performed (...). They took part in the attacks of Csucs-Borossebes-Ocsod and they stood out especially when attacking the bridge head from Szolnok, supported by their own artillery, they had outflanked and attacked the enemy who had been supported by the various artillery units deployed on both banks of Tisa River. In this attack the Beius
Regiment went forward under enemy fire in perfect order without halting $6 \mathrm{kms}$ on a smooth ground (open ground) until reaching bayonets. Out of the enemy forces, only those who had chariots at their disposal escaped" 57 .

A possible explanation of this difference in attitude seems to have been, besides an adequate training, the moral preparation of the troop. Before marching to battle, they had been gathered in the Orthodox Church from Tebea in order to take The Oath, with the regiment flag emerging from Avram Iancu's tomb. There, Colonel Gheorghe Rascoviceanu, commander of $9^{\text {th }}$ Light Infantry Regiment, told them as it follows: "Soldiers, I hereby tell you today under the evergreen oak of Horia the Martyr, before the tomb of Avram Iancu, former King of the Mountains. I hereby tell you today in the great hour, in the supreme hour of the redemption of our Folk. And I hereby tell you: may all your limbs tremble before the memory of all those who during centuries had whitened with their bones, the land of the Folk long and wide to get where we are and to become what we are. Be proud that fate has still chosen you, people of Apuseni Mountains, has decided that you be the first from all Transylvania, to do The Oath of faith and sacrifice for our beloved Homeland (... $)^{58}$.

The regiment had been formed in Brad, between $9^{\text {th }}$ and $10^{\text {th }}$ Light Infantry Regiments, and had constituted ever since a part of $4^{\text {th }}$ Light Infantry Brigade, taking part in all exercises, marches and maneuvers, day and night together with them, which seem to have influenced the morale both of the troop as well as officers' ${ }^{59}$, considered by Transylvanian Troops HQ as very good ones. Besides, General Ștefan Panaitescu was reporting that during the 40-day period as long as they remained in direct contact with light infantry regiments, between officers and the Beiuş Regiment troops, the most graceful harmony reigned.

\section{Conclusions}

From the chronological exposition of the steps related to this topic, one should understand that at the moment the two legal acts had been issued,

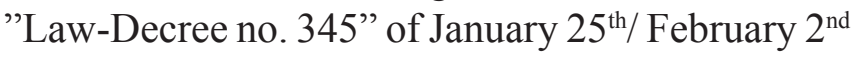
1919 , respectively "Decision no.40" of January $26^{\text {th }}$ / February $3^{\text {rd }} 1919$, Consiliul Dirigent had already published "Decree no. I" under which Hungarian legislation, laws, ordinances, regulations and legal 
statues issued prior to October $18^{\text {th }} 1918$, were temporary in force.

However, one cannot support the idea that when the bills of the two legal acts had been drafted, the minister of war, General Arthur Văitoianu, could have been aware with the way military justice was administered within Transylvanian divisions, especially that the report of General Ioan Boeriu addressed to the Ministry of War, although dated February $18^{\text {th }} 1919$, had been registered by the Ministry of War no sooner than March $3^{\text {rd }} 1919$, under no. 7095.

Also, nothing entitles us to assert the hypothesis according to which, had he known these aspects, General Arthur Văitoianu would have adopted another measure, unlike that which, starting from January $24^{\text {th }} /$ February $6^{\text {th }} 1919$, all regulations and all Romanian military laws became also applicable to the units comprised by Transylvanian divisions.

The system of a common military justice, difficult to be applied to the two entities which made up the Transylvanian Troops HQ, and we refer here to the regular troops from the Old Kingdom, and the $6^{\text {th }}$ and $7^{\text {th }}$ Army Corps Transylvanian divisions, had a visible impact upon the disciplinary state from some units of the latter.

Poorly equipped, with a reduced number of assigned officers, aspect which could be found more visibly within the precarious discipline level, but above all, with the troop marked by long years of war and affected by the wind of Bolshevik revolution, some of these units have not confirmed, being withdrawn from the front in order to carry out a training period, where they were used for guarding objectives, as well as to other preponderantly-administrative activities.

It is worth mentioning that in June 1919, in order to reestablish military order and discipline, other types of measures were taken, besides warning division commanders. Therefore, within $16^{\text {th }}$ Infantry Division, dismissal of all four commanders of infantry regiments was ordered, Colonels Pompet Bersan, Carol Divisioli, Adolf Reiner and Henrich Brandsch, who were replaced by officers from the Old Kingdom Romanian army structures $^{60}$.

Obviously, Transylvanian Troops HQ made a direct correlation between troop disciplinary state and dysfunctional military justice within normal parameters, due to non-unitary legislation and lack of specialized personnel, trained lawyers or magistrates, available to be assigned to courts martial.

In the documentation of the current material we have encountered many demobilization requests from some officers in reserve, magistrates or lawyers in civilian life, who were invoking different reasons to be left aside, requesting even their replacement with other magistrates who had not been called to mobilization yet, or who were proposing a rotation system for the mobilization of magistrates.

Besides, even the Ministry of Justice was cautious when granting magistrates' mobilization, due to the great number of issues that was facing, and economic, social and legislative reforms underway, so that, at the repeated requests from the Romanian General Headquarters, to this end, the answer was usually negative: "We requested the Ministry of Justice to allow at our disposal a number of 10 magistrates, officers in reserve, absolutely necessary for the completion of courts martial within the operational area", reported JAG, General Gheorghe Cereseanu, "[but] I was given the answer by the secretary general that due to expropriation, compensations and electoral offices, it could not have any magistrate available for military justice" ${ }^{\prime \prime}$.

Regarding the legislative differences we presented, we should add the idea that they had been part of a natural process, a chance taken, we believe, by the great political figures of that time on both sides of the Carpathians: "sudden removal of laws and lawful institutions, which had been in the neighboring territories, would not have contributed to the union of the soul, which every good patriot desired, and could not even have been realized without great difficulty. It was therefore inevitable, that for a transitional period (...) the laws that had dominated in the neighboring provinces before $1919 " 62$ to remain into force.

There have also been other disputes regarding legislation between Transylvania and the Old Kingdom. We could quote to this end the refusal of Transylvanian Bars of Lawyers to accept among its members lawyers from the Old Kingdom, due to differences in university training between the two categories of the same guild; the lawyers from the Old Kingdom could profess after faculty, whereas their homologous Transylvanian had to have, 
besides the title of $\mathrm{PhD}$ in law, a number of years of practice $^{63}$.

Legislative differences had not been solved even after the adoption in 1923 of the New Constitution ${ }^{64}$, which provided under art.137 that: "All existing codes and laws shall be revised in different parts of the Romanian state, in order to be compatible with the current Constitution and to ensure legislative unity. Until then they are in force". It was only in 1938 when, consequent to the reforming process of justice and its inherent legislation, one could talk about legal, legislative, administrative and judicial unification of the new Romanian provinces ${ }^{65}$.

As far as the Transylvanian volunteering units are concerned, a couple of years later, General Henri Cihoski wrote ${ }^{66}$ that during the crowning parade ceremony from Alba Iulia, General Dănilă Papp presented $18^{\text {th }}$ Division "in such [good] conditions" that he was decorated with the "The Crown of Romania" Order, in Rank of Great Officer.

\section{NOTES:}

1 Cristina Rotaru-Radu, "Unification of criminal legislation after the Great Union of 1918", National Conference "Romanian Law 100 years after the Great Union", Faculty of Law of the University of Bucharest, November 22-23, 2018, https://drept.unibuc.ro/dyn_doc/ conferinta/brosura $\% 20$ conferinta $\% 20100 \% 20 \mathrm{de} \% 20$ ani $\% 20$ update.pdf, accessed on 10.05.2021.

2 Dumitru Preda, Vasile Alexandrescu, Costică Prodan, În apărarea României Mari. Campania armatei române din 1918-1919, Encyclopedic Publishing House, Bucharest, 1994, p. 77.

3 *** History of the Romanian infantry, Scientific and Pedagogical Publishing House, Bucharest, 1985, vol. II, p. 149.

4 Dumitru Preda, Vasile Alexandrescu, Costică Prodan, op.cit, p. 132.

5 Dumitru Preda, Vasile Alexandrescu, Costică Prodan, op.cit, p. 91

6 Ibidem, p.1 02.

7 Ibidem, p. 131.

8 Ibidem, p. 149.

9 Ibidem.

10 Mihail E. Ionescu (coordinator), Romanians in the Great War: 1915. Documents, impressions, testimonies, Military Publishing House, Bucharest, 2015, p. 227.

11 Ibidem, p. 228.

12 Mihail E. Ionescu, coordinator, op.cit., p. 256.

13 Ibidem, p. 229.

14 Dumitru Preda, Vasile Alexandrescu, Costică

Prodan, op.cit, p. 154.

15 Monitorul Oficial, no. 243 from 26.01.1919, p. 4784.

16 Ibidem.

17 Glenn E. Torrey, Romania in the First World War, Meteor Publishing House, Bucharest, 2014, p. 345.
18 Cornel Țucă, Laurențiu Batin, Transylvanian and Bucovina officers from the former Austro-Hungarian army, Ethnologia Publishing House, Baia Mare, 2018, p. 35.

19 Dumitru Preda, Vasile Alexandrescu, Costică Prodan, op.cit, p. 156.

20 Ibidem.

21 Ibidem.

22 [AMNR], fond microfilme, Ministry of War, Section III justice, FII.5.1852, file no. 20, f. 453-454.

23 Ibidem, f. 453.

24 [AMNR], fond Marele Cartier General, crt. 1990, f. 118. 25 Ibidem, f. 327.

26 [AMNR], fond microfilme, Ministerul de Război, Section III justice, FII.5.1852, file no. 20, f. 450.

27 Gazeta Oficială, no. 6 from 14/27 January 1919, p.1.

28 Gazeta Oficială, no. 16 from 27 February/12 March 1919, p. 3

29 The territory of Solnoc-Dăbâca County has been divided among Cluj County (the center and the South, including the city of Dej), Maramureș County (the North), Bistrița-Năsăud County (the East) and Sălaj County (the West), https://ro.wikipedia.org/wiki/Comitatul_Solnoc-D\%C4\% $83 \mathrm{~b} \% \mathrm{C} 3 \% \mathrm{~A} 2 \mathrm{ca}$, accessed on 07.05.2021.

30 [AMNR], Biblioteca arhivistică, crt.1390, f. 147.

31 [AMNR], fond microfilme, Ministry of War, Section III justice, FII 5.1852, ds.49, f. 453.

\section{Ibidem.}

33 Monitorul Oficial, no.127, 29 August 1918, pp. 2040-2041.

34 [AMNR], fond microfilme, Ministerul de Război,

Secția a III-a justiție, FII 5.1852, ds.49, f.453v.

35 Ibidem, f.450.

36 Gazeta Oficială, no. 31-35, from 25-31 May, 5,12,16 June 1919, p. 5.

37 [AMNR], fond Marele Cartier General, crt.1990, f. 118.

38 Ibidem, f.57.

39 Ibidem, f.72.

40 Ibidem, f.73.

41 Ibidem, f. 59-61.

42 [AMNR], fond Marele Cartier General, crt.1990, f. 59-61.

43 Ibidem, crt. 2568, f. 149.

44 Ibidem, crt. 2568, f. 172.

45 Ibidem, crt.3215, f. 88.

46 Ibidem, crt. 2568, f. 126.

47 Ibidem, f. 174.

48 Ibidem, f. 299.

49 Ibidem, f. 332.

50 [AMNR], fond Marele Cartier General, Section Justiție, file crt.2568, f. 584

51 Ibidem, dosar crt.1990, f. 308.

52 Ibidem.

52 Ibidem, f. $308 \mathrm{v}$.

54 [AMNR], fond Marele Cartier General, Section Adjutantură, file 3215, f.122.

55 Ibidem, f. 123.

56 http://enciclopediaromaniei.ro/wiki/Regimentul_de_ voluntari_Horea, accessed on 09.05.2021.

57 [ĀMNR], fond Marele Cartier General, crt.1990, f. 111.

$58 \mathrm{http} / / /$ enciclopediaromaniei.ro/wiki/Regimentul_de voluntari_Horea, accessed on 09.05.2021.

59 [ĀMNR], fond Marele Cartier General, crt.1990, f. 112. 
60 [AMNR], fond Marele Cartier General, crt.1990, f. 099.

61 Ibidem, crt.2568, f. 185v.

62 Cristina Rotaru-Radu, "Unification of criminal legislation after the Great Union of 1918", National Conference "Romanian Law 100 years after the Great Union", Faculty of Law of the University of Bucharest, November 22-23, 2018, https://drept.unibuc.ro/dyn_doc/ conferinta/brosura $\% 20$ conferinta $\% 20100 \% 20 \mathrm{de} \% 20$ ani $\% 20$ update.pdf, p. 12.

63 Vasile Stăncescu, „Avocații din Regat și Avocaţii din Ardeal", Curierul justiției militare, 15 March 1922, [AMNR], Biblioteca arhivistică, crt.1390, f. 180.

64 http://www.cdep.ro/pls/legis/legis_pck.htp_act_text? $\mathrm{idt}=1517$, accessed on 07.05.2021.

65 https://www.unbr.ro/unificarea-si-integrarea-juridi ca-a-romaniei-consecinta-a-actului-de-la-1-decembrie1918-cu-privire-speciala-asupra-transilvaniei-alocutiunesustinuta-de-dl-prof-univ-dr-ioan-santai-la-alba-iul/, accessed on 07.05.2021.

66 [AMNR, fond Direcția Cadre și Învățământ, Memorii Bătrâni, litter P, gl. Papp, file 68, f. 10.

\section{REFERENCES}

*** History of the Romanian infantry, Scientific and Pedagogical Publishing House, Bucharest, 1985.

*** Unification of legislation and functioning of the judiciary after the Great Union of 1918, Collection of articles made by NIJ auditors and INM auditors, Universul Juridic Publishing House, Bucharest, 2018.

Ionescu Mihail E., (coordinator), Romanians in the Great War: 1915. Documents, impressions, testimonies, Military Publishing House, Bucharest, 2015.

Preda Dumitru, Alexandrescu Vasile, Prodan Costică, In defence of Greater Romania. The campaign of the Romanian army from 1918-1919, Encyclopedic Publishing House, Bucharest, 1994.
Rotaru-Radu Cristina, "Unification of criminal legislation after the Great Union of 1918", National Conference "Romanian Law 100 years after the Great Union", Faculty of Law of the University of Bucharest, November 22-23, 2018, https:// drept.unibuc.ro/dyn_doc/conferinta/brosura $\% 20$ conferinta $\% 20100 \% 20 \mathrm{de} \% 20 \mathrm{ani} \% 20$ update.pdf

Rotaru-Radu Cristina, „Unificarea legislației și funcționarea sistemului judiciar după Marea Unire din 1918", Universul Juridic Publishing House, Bucharest, 2018.

Torrey Glenn E., Romania in the First World War, Meteor Publishing House, Bucharest, 2014.

Țucă Cornel, Batin Laurențiu, Transylvanian and Bucovina officers from the former AustroHungarian army, Ethnologia Publishing House, Baia Mare, 2018.

*** Gazeta Oficială, no. 6, from 14/27 January 1919.

*** Gazeta Oficială, no. 31-35, from 25-31 May, 5, 12, 16 June 1919.

*** Monitorul Oficial, no. 243, 26 January 1919.

*** Monitorul Oficial, no. 127, 29 August 1918.

http://enciclopediaromaniei.ro/wiki/Regim entul_de_voluntari_Horea

http://www.cdep.ro/pls/legis/legis_pck.htp_ act text?idt=1517

https://drept.unibuc.ro/dyn_doc/conferinta/ brosura $\% 20$ conferinta $\% 20100 \% \overline{2} 0 \mathrm{de} \% 20$ ani $\% 20$ update.pdf

https://ro.wikipedia.org/wiki/Comitatul_ Solnoc-D $\%$ C4\%83b\%C3\%A2ca

https://www.unbr.ro/unificarea-si-integrareajuridica-a-romaniei-consecinta-a-actului-de-la1-decembrie-1918-cu-privire-speciala-asupratransilvaniei-alocutiune-sustinuta-de-dl-prof-univdr-ioan-santai-la-alba-iul/ 